\title{
Concha bullosa of inferior turbinate: a rare cause of nasal obstruction
}

\author{
Alt konkada konka bülloza: Burun tıkanıklğgının nadir bir nedeni
}

Gürkan Kayabaşoğlu, Recep Kaymaz, Mahmut Sinan Yılmaz

Department of Otolaryngology, Medical Faculty of Sakarya University, Sakarya, Turkey

\begin{abstract}
Nasal obstruction is a common health problem in our society. Concha bullosa, which is pneumatization of conchas, is one of the causes of nasal obstruction and usually seen in middle turbinates. Hypertrophy of conchal mucosa is the most common cause of conchas-related nasal obstruction and mostly involves the inferior turbinates. In this article, we present a 14-year-old female case who suffered from nasal obstruction originated from inferior concha bullosa, a rarely reported case in the literature.
\end{abstract}

Key Words: Concha bullosa; inferior concha; nasal blockage.

Nasal obstruction is a common health problem. Excluding reasons related to the septum, the most common structure causing stuffy nose is the inferior nasal turbinate. ${ }^{[1]}$ The nasal turbinates help to warm, moisten and filter the air breathed in. Most of the inhaled air passes through the middle and inferior turbinates. The inferior turbinate is the largest of all and it is responsible for directing nasal airflow. The middle turbinate is smaller and it prevents direct contact with pressured nasal airflow by covering the maxillary and ethmoidal sinus ostia. A concha bullosa is a pneumatized cavity within a turbinate that usually occurs in the middle turbinate. Mucosal hypertrophy is an important cause for nasal obstructions that is often seen in the inferior turbinate. Allergy, exposure to environmental irritants or persistent sinus infections can result in mucosal hypertrophy. ${ }^{[2]} \mathrm{A}$ concha bullosa can rarely cause enlargement of the inferior turbinate. We present the rare case of a patient admitted with stuffy
Burun tıkanıklığı, toplumumuzda genel bir sağlık sorunudur. Konkaların pnömatizasyonu olan konka bülloza burun tıkanıklığının nedenlerinden biri olup, genellikle orta konkalarda görülür. Konka mukozasında hipertrofi, konka ile ilişkili burun tıkanıklığının en sık görülen nedeni olmakla birlikte, en sık alt konkayı tutar. Bu yazıda, literatürde nadiren bildirilen bir durum olup, alt konka büllozadan kaynaklı burun tıkanıklığı olan 14 yaşında bir kadin olgu sunuldu.

Anahtar Sözcükler: Konka bülloza; alt konka; burun tıkanıklığı.

nose caused by concha bullosa located in the inferior turbinate.

\section{CASE REPORT}

A 14-year-old female was admitted to our clinic with complaint of stuffy nose. She had no allergic complaints. On examination, the nasal septum was deviated toward the left and the right inferior turbinate was hypertrophic. The hypertrophy did not lessen with placement of cotton soaked in 2:100 pantocaine with 1:10000 adrenaline. Endoscopic nasal examination revealed that the right middle turbinate was also hypertrophic. A coronal paranasal sinus computed tomography (CT) scan confirmed nasal septal deviation toward the left and that the right middle and inferior concha were pneumatized and hypertrophic. The paranasal sinuses appeared normal (Figure 1,2). The patient underwent endoscopic partial resection of the right middle 


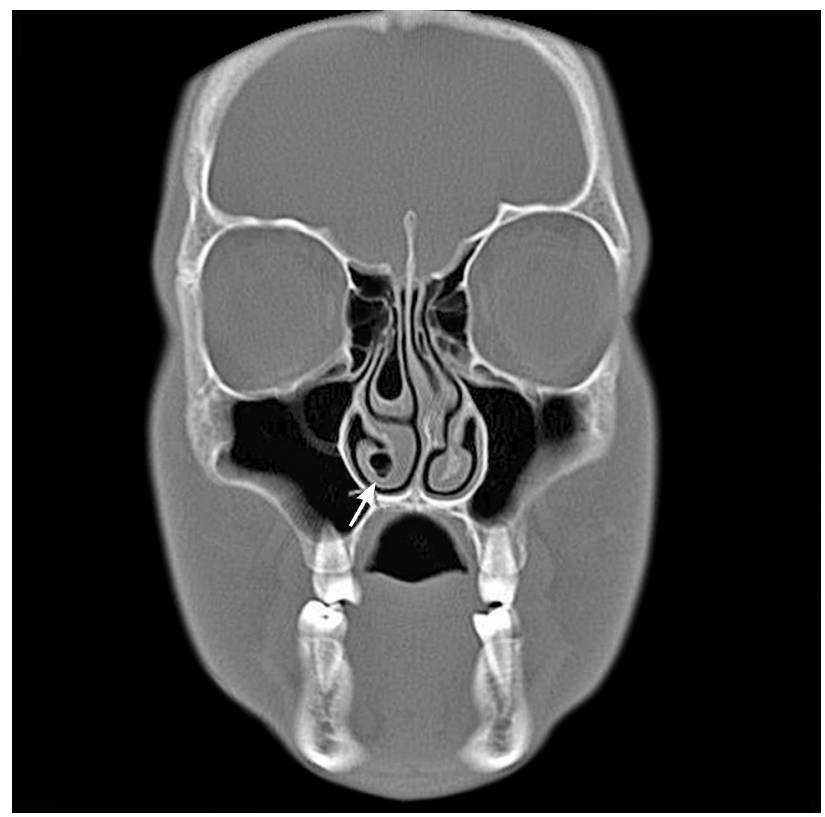

Figure 1. Coronal computed tomography scan shows hypertrophic inferior turbinates with right concha bullosa.

concha, punch-crushing of the right inferior concha, septoplasty and out-fracturing of both inferior concha under sedoanalgesia with $2 \mathrm{mg}$ midazolam and $50 \mathrm{mg}$ fentanyl. The complaints of stuffy nose disappeared on postoperative follow-up.

\section{DISCUSSION}

Inferior turbinate hypertrophy is a common cause of stuffy nose, and generally develops due to allergy, vasomotor rhinitis or chronic sinus infections. Nasal septal deviation can also cause compensatory inferior turbinate hypertrophy. Aeration of the turbinate, termed "concha bullosa," is a common anatomical variant of intranasal anatomy. It is seen in approximately $34 \%$ of all paranasal sinus CT scans and most do not cause any symptoms. ${ }^{[3]}$

However, inferior turbinate hypertrophy associated with inferior concha bullosa is rather uncommon. To our knowledge, it has been reported in less than 20 cases in the national and international medical literature.

The inferior conchae develop by endochondral ossification of a pair of chondral lamella, mesethmoid and ectoethmoid components. The different ossification centers meet in the fifth to seventh weeks of fetal life. ${ }^{[4]}$ During the ossification process, the inferior concha separates from the ectoethmoid and becomes an independent bone structure. ${ }^{[5]}$ Meanwhile, epithelium

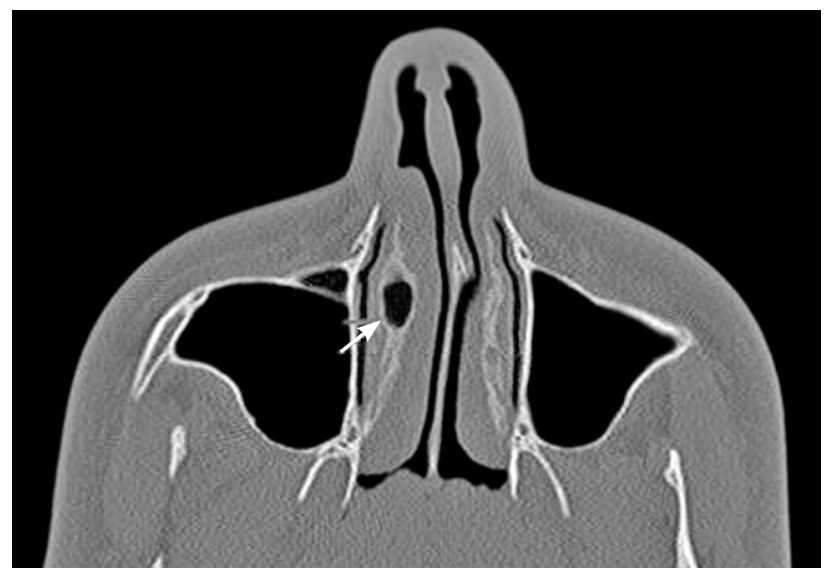

Figure 2. Axial computed tomography scan shows hypertrophic turbinates with right concha bullosa.

can be invaginated into two lamellae and can take the form of a bullous concha. ${ }^{[4]}$

Normally, inferior concha bullosa has an asymptomatic course and diagnosis is made incidentally during imaging. ${ }^{[6-8]}$ However, as in our case, it can lead to stuffy nose by causing inferior turbinate hypertrophy. Aydin et al. ${ }^{[6]}$ identified two cases of inferior concha bullosa. In one asymptomatic case, diagnosis was made incidentally on CT for a palatal mass whereas the other patient had complaints of stuffy nose, nasal discharge and facial pain.

It is very difficult to distinguish inferior turbinate hypertrophy from inferior concha bullosa. Topical vasoconstrictor drugs can be helpful in distinguishing mucosal hypertrophy from concha bullosa. Definitive diagnosis is made with a sinus CT scan.

The classification of concha bullosa has three types: pneumatization of the vertical lamella, pneumatization of the inferior bulbous and "true" concha bullosa that include both. ${ }^{[9]}$ In our case, the pneumatization was localized in the inferior bulbous of the inferior turbinate, which is compatible with most cases in the literature.

Inferior concha bullosa should be treated if it causes stuffy nose and other symptoms. The goal of the therapy is to maximize the airway while preserving mucosal functions. Medical treatment is usually beneficial in mucosal hypertrophies, but it is not successful in treating concha bullosa. Many surgical techniques have been described for treatment of inferior concha bullosa, including out-fracturing, compressing or crushing with forceps, excision of one edge of the concha with its mucosa using scissors, and submucosal conchal bone resection with microdebrider ${ }^{[2,7,10]}$ In this case, our method of choice was to compress 
the inferior concha with a forceps. Although this technique is easy and quick to perform, it is preferred in relatively small pneumatizations. It is helpful in both maintaining mucosal integrity and widening of the airway. A disadvantage of the technique is inadequate treatment or recurrence of bullosa due to uncertain degree of crushing during operation. Total resection of the inferior concha is contraindicated because it has serious side effects. ${ }^{[11,12]}$

\section{Conclusion}

Concha bullosa of the inferior turbinate is a rare entity. It is usually diagnosed incidentally on CT scans, but also can present with symptoms of nasal obstruction. It is best treated surgically using various techniques.

\section{Declaration of conflicting interests}

The authors declared no conflicts of interest with respect to the authorship and/or publication of this article.

\section{Funding}

The authors received no financial support for the research and/or authorship of this article.

\section{REFERENCES}

1. Hilberg O, Grymer LF, Pedersen OF, Elbrønd O. Turbinate hypertrophy. Evaluation of the nasal cavity by acoustic rhinometry. Arch Otolaryngol Head Neck Surg
1990;116:283-9.

2. Ingram WA, Richardson BE. Concha bullosa of an inferior turbinate. Ear Nose Throat J 2003;82:605-7.

3. Zinreich SJ, Mattox DE, Kennedy DW, Chisholm HL, Diffley DM, Rosenbaum AE. Concha bullosa: CT evaluation. J Comput Assist Tomogr 1988;12:778-84.

4. Cankaya H, Egeli E, Kutluhan A, Kiriş M. Pneumatization of the concha inferior as a cause of nasal obstruction. Rhinology 2001;39:109-11.

5. Moss-Saletjin L, Anatomy and embryology. In: Blitzer A, Lawson W, Friedman W, editors. Surgery of the paranasal sinuses. Philadelphia: W. B. Saunders; 1991. p. 1-25.

6. Aydin O, Ustündağ E, Ciftçi E, Keskin IG. Pneumatization of the inferior turbinate. Auris Nasus Larynx 2001;28:361-3.

7. Unlu HH, Altuntas A, Aslan A, Eskiizmir G, Yucel A. Inferior concha bullosa. J Otolaryngol 2002;31:62-4.

8. Akagun F, Erdogan BA, Bora F. Pneumatization of bilateral inferior turbinates: case report. Medical Journal of Bak1rkoy 2013;9:36-8.

9. Bolger WE, Butzin CA, Parsons DS. Paranasal sinus bony anatomic variations and mucosal abnormalities: $\mathrm{CT}$ analysis for endoscopic sinus surgery. Laryngoscope 1991;101:56-64.

10. Ozcan KM, Gedikli Y, Ozcan I, Pasaoglu L, Dere H. Microdebrider for reduction of inferior turbinate: evaluation of effectiveness by computed tomography. J Otolaryngol Head Neck Surg 2008;37:463-8.

11. Clement WA, White PS. Trends in turbinate surgery literature: a 35-year review. Clin Otolaryngol Allied Sci 2001;26:124-8.

12. Pittore B, Al Safi W, Jarvis SJ. Concha bullosa of the inferior turbinate: an unusual cause of nasal obstruction. Acta Otorhinolaryngol Ital 2011;31:47-9. 